\title{
Utilizing Virtual Team: Lessons Learned from MMORPGs Players
}

\author{
Lin Chien Chiang ${ }^{1}$ \\ ${ }^{1}$ Department of Business Administration, Shih Hsin University, Taipei City, Taiwan \\ Correspondence: Lin Chien Chiang, Department of Business Administration, Shih Hsin University, No. 111, Sec. 1, \\ MuCha Rd., Taipei City, Taiwan. Tel: 886-933-697-310. E-mail: Randolph.shu@gmail.com
}

Received: April 10, 2016

Accepted: April 16, 2016

Online Published: April 16, 2016

doi:10.5430/jbar.v5n1p42

URL: http://dx.doi.org/10.5430/jbar.v5n1p42

\begin{abstract}
Virtual teams, with the advantage of bridging over geographical and temporal restriction, have been widely utilized by companies around the world to make the best use of talents from different domains and areas to accomplish complex missions and assignments. However, it is always a challenging task to build up a perfect environment for virtual teams to deliver outstanding performance.

The current study utilized online survey to collect data from MMORPGs (Massive Multiplayer Online Role Play Games) players, a special type of virtual team, to investigate critical issues on the journey of attaining operational goals. The major objective is to figure out relationships among different factors that were proposed, from the literature or practical evidences, to affect the performance of virtual teams. The results are concluded as follows: (1) Trust among virtual team members has positive influences on team cooperation; (2) The cohesiveness of virtual team members has positive influences on team cooperation; (3) Team cooperation has positive influences on team performance; (4) Communication among virtual team members would decrease the influence of team cooperation on team performance. Managerial implication and directions for further studies are provided at the end of the current study.
\end{abstract}

Keywords: Virtual team, Trust, Cohesiveness, Team cooperation, Team communication

\section{Introduction}

\subsection{Background}

Cooperation is crucial for completing tough tasks in modern days; with the advancement of information technology, integrating talents located in different areas to accomplish tasks becomes viable and necessary to meet various requirements (Shes \& Guzzo, 1987). Utilizing virtual teams to solve complex missions and to secure competitive advantage is a common practice for many companies. The idea of establishing virtual teams is to exploit the information technology to cross the temporal as well as spatial boundaries; companies would then not be limited by the location of the offices or buildings and could improve flexibility and adaptivity. The rapid emergence and astonishing evolvement of the information technology made it possible to communicate and to cooperate with others remotely. Indeed, the advancement of information technology laid a solid foundation for cooperation; however, in the context of virtual team cooperation, the ultimate performance might still be jeopardized without devoted cooperation among members, an unhindered two-way communication, a trustworthy atmosphere, and the cohesiveness among team members.

\subsection{Rationale \& Importance of the Current Study}

The major objective of the current study is to identify factors that might affect the performance of virtual teams; specifically speaking, by collecting data from players of Massive Multiplayer Online Role Play Games (MMORPGs), the author tries to figure out the effects of cohesiveness, trust, tendency of cooperation, and communication on team performance. Academia and practitioners have recently paid lots of attention to the development of MMORPGs because, during the process of accomplishing task and achieving objectives, players of MMORPGs must actively participate in cooperation with other players; therefore, players of MMORPGs are considered as quite similar to members of virtual teams during the process of realizing goals. Further understanding behaviors of MMORPGs players would not only help appreciate the value of virtual team but also recognize the chemistry embedded in the interactions among virtual team members (Chang \& Lin, 2014; Hou, 2012; Wang, Kuo, \& Yang, 2011). As virtual team becomes a common practice for companies to conduct daily operations, its quite urgent for academia as well as 
practitioners to dissect the mechanism that might improve the productivity of virtual team since the very essence of virtual teams is quite different from traditional co-located teams. As cooperation, cohesiveness, communication, and trust are major factors to be investigated in the current study, literature about virtual team and those factors are provided in the following section.

\subsection{Review of Literature \& Development of Hypotheses}

\subsubsection{Virtual Team}

Virtual team has played an essential role in the daily operations of different organizations; it's also a hot topic for scholars from divers areas (Bosch-Sijtsema, 2007; Brahm \& Kunze, 2012; O’Leary \& Mortensen, 2010). Traditionally, team members work for the same organization; they are quite familiar with cooperating in a face-to-face manner. However, the pressure of globalization, the competition from rivals around the world, and the scarcity of precious resources, make virtual teams a compelling weapon for surviving and thriving in the fast changing business environment (Khazanchi \& Zigurs, 2005). Members of virtual teams, on the contrary, might come from different organizations, different continents, or even live in different time zones; without face-to-face communication, Internet and information technology are critical instruments for communication, for discussion, and for successfully completing various tasks. The emergence of virtual teams not only drastically changed the operational patterns of organizations but also blurred the boundaries among organizations (Hertel, Konradt, \& Orlikowski, 2004; Lipnack \& Stamps, 1997). However, before praising the virtues of virtual teams, it should be noted that virtual teams cannot be considered as a magic pill for dealing with every challenge confronted by modern organizations; the advantages brought by utilizing virtual teams are considered strategically important and indispensable in the global marketplace, but every rose has its thorns (Bergiel, Bergiel, \& Balsmeier, 2008). Without a careful planning, virtual team could end with disaster instead of any positive outcomes.

Two definitions of virtual team could be found from the literature: (1) members of a virtual team might come from different organizations or from the same organization; they utilize information technology for crossing the boundaries of organizations, and for overcoming temporal and spatial limitations (Igbaria \& Guimaraes, 1999; Lipnack \& Stamps, 1997; Lipnack \& Stamps, 1999); (2) members of a virtual team might come from different countries (distributed locations); they might not be able to see each other face to face, therefore, cultural differences are quite common among different virtual team members (Canny \& Ward, 1999; Johnson, 1973; Maznevski \& Chudoba, 2000). In essence, several characteristics of virtual teams are identified as follows: the main purpose to establish a virtual team is to rapidly integrate resourced distributed in different areas, members of a virtual team get together temporally for accomplishing specific tasks, members of a virtual team communicate with each other through digital medium, and finally cultural diversity is not only quite common but also considered as critical assets for the virtual team (Leenders, Engelen, \& Kratzer, 2003; Staples \& Zhao, 2006).

\subsubsection{Team Performance}

Team performance is the ultimate indicator to examine whether a team efficiently and effectively achieves team goals (Barrick, Stewart, Neubert, \& Mount, 1998; Oh, Labianca \& Chung, 2006). Specifically speaking, team performance is the degree of satisfying preset criteria achieved by the team, such as: quality, cost, and completing time (Hoegl \& Gemuenden, 2001). In practice, performance of the results and performance of the process are both critical aspects for measuring team performance (Wallace, Keil, \& Rai 2004). A previous study used a three-pronged approach to evaluate team performance, include: the degree of achieving team goals, the efficiency of completing tasks, and the relationships among team members (Patrashkova-Volzdoska, McComb, Green, \& Compton, 2003).

After reviewing studies on virtual teams, Politis (2003) indicated that the IPO (Input-Process-Output) structure commonly utilized for measuring traditional team performance could be modified for analyzing performance of virtual teams. Characteristics and composition of virtual teams are critical input variables; social emotional processes deal with the construction of relationships among virtual team members and the cooperation among members of virtual teams are considered crucial process variables; the outcome and the satisfaction of virtual team members are important output variables.

\subsubsection{Team Cooperation}

In order to survive in the environment with high complexity and rapid changes, independent workers have to cooperate with others to complete different tasks; sometimes crossing temporal and spatial boundaries is necessary for delivering positive outcomes (Nemiro, Beyerlein, Bradley, \& Beyerlein, 2008). Flexibility and adaptivity are critical elements for remaining competitive in the global marketplace (Lin, Baruch, \& Shih, 2012). Team cooperation is defined as the process of two or more team members, by utilizing resources, knowledge, and information 
technology, to work together for pursuing shared goals, completing assigned tasks, and receiving mutual benefits (Sheng, Siau, \& Nah, 2010). In essence, team cooperation is a set of behaviors performed by members of a specific team; those task-dependent members would integrate their domain knowledge and coordinate with one another to achieve a common goal (Malone \& Crowston, 1994). Team cooperation is inevitable for improving effectiveness (Chatman \& Flynn, 2001; Cohen, Ledford, \& Spreitzer, 1996), and is the key to ensure the team could achieve objectives properly (Lin, Baruch, \& Shih, 2012; Van de Ven, Delbecq, \& Koening, 1976).

Team cooperation won't be realized without careful planning and unhindered communication; those mechanisms would not only be crucial for the accomplishment of tasks in a steady and predictable manner but also help team members to generate positive outcomes in both formal and informal ways (Kraut \& Streeter, 1995; Rico, Sánchez-Manzanares, Gil, \& Gibson, 2008). Setting proper goals is also quite important to trigger cooperation (Canney-Davison \& Ward, 1999); as shared goals and shared benefits being recognized and accepted by team members, cooperation would become viable and indispensable for accomplishing those goals. Task dependence and outcome dependence had long been proved to increase the willingness to cooperate and to encourage communication among team members (Johnson, 1973; Shannon \& Weaver, 1949).

Team cooperation is promising but not without drawbacks. Groupthink might restrain the creativity of team members and end up with a compromised instead of an optimal solution (Ellis, Hollenbeck, Illgen, Porter, West, \& Moon, 2003); moreover, team cooperation might decrease motivation and trigger social loafing behaviors for some team members (Karau \& William, 1993). However, from a holistic point of view, the benefits of team cooperation are still worth pursuing. With the formation of norms and patterns for cooperation, team members would become more capable of handling specific tasks (García \& Velasco, 2002); it is also less time-consuming and effortless for experienced teams to accomplish difficult jobs (Gersick \& Hackman, 1990). Actually, the establishment of cooperative norms would have positive effects on team performance because, during the process of achieving goals, team members could easily predict responses as well as reactions of others reduce the uncertainty, increase the productivity, and minimize the anxiety (Cohen, Ledford, \& Spreitzer, 1996).

However, it is not easy for virtual team members to cooperate with others; different techniques and activities have been proposed to increase the cooperation among virtual team members, such as organizing regular face-to-face meetings (Maznevski \& Chudoba, 2000), applying information technologies (Majchrzak, Rice, King, Malhotra, \& Ba, 2000a; Majchrzak, Rice, King, Malhotra, \& Ba, 2000b; Tan, Wei, Huang, \& Ng, 2000), and hosting outdoor activities to minimize perceptual gaps among team members (McLean, 2007; Robey, Khoo, \& Powers, 2000). In the current study, team cooperation is considered as the cooperative relationship among partners to utilize resources at hand, knowledge from different domains, and information technology to pursue common goals, complete various missions, and share benefits.

It would be a commonly agreed fact that team cooperation plays a crucial role during the process of accomplishing tasks; team performance would be seriously damaged if members of virtual team could not cooperate with others through the utilization of different information technology tools; the first hypothesis is then stated as follows:

\section{H1: Team cooperation among virtual team members will positively affect performance of the virtual team.}

\subsubsection{Trust}

Psychologists consider "trust" as the belief or expectation from the trustor to the trustee. Deutsch (1977) described trust as the confidence that an individual would find what is desired from another, rather than what is feared. In the context of virtual team, trust could be considered as a belief that other members would pursue a common goal and achieve mutual objectives for the benefits of all members (Meyerson, Kramer, \& Weick, 1996; Politis, 2003). With the existence of trust, team members will share information and take risk about information exchange (Daely \& Vasu, 1008; Nahapiet \& Ghoshal, 1998). Trust could also encourage team members to help each other, to actively engage in various tasks, and to transform tacit knowledge into explicit knowledge for practical use (Connelly \& Kelloway, 2003). In other words, trust could be considered as the interdependent relationship among different parties of the same group to hold positive and optimistic expectation about other members in uncertain situations (Chiu, Hsu, \& Wang, 2006; Garrison, Wakefield, Xu, \& Kim, 2010; Lane, 1998; Tsai \& Ghoshal, 1998). Previous studies about virtual team concluded that trust among team members could be considered as a kind of social capital that could lead to cooperative behavior (Chiu, Hsu, \& Wang, 2006; Connelly \& Kelloway, 2003; Putnam, Leonardi, \& Nanetti, 1994).

Hypothesis 2 is then formulated as follows:

H2: Trust among virtual team members will positively affect the cooperation among virtual team members. 


\subsubsection{Cohesiveness}

Cohesiveness is the desire of individuals to maintain their membership of a group; during the process of working with other members for achieving common goals or completing various missions, cohesiveness would be strengthened (Festinger, Schachter, \& Back, 1983). In essence, team cohesiveness is the mutual recognition of the relationship among members, and the collective believe of common goals and values as well (Furumo \& Pearson, 2006; Robert, Dennis, \& Hung, 2009; Robbins, 1991). It's generally recognized that team members with high cohesiveness would pay more efforts to accomplish missions, depend more on other members, and be more willingly to exchange information with others that would then improve the performance of the team (Tan, Wei, Huang \& $\mathrm{Ng}$, 2000). A previous study also indicated that, with high cohesiveness, team members would be more satisfied about the team and be more willingly to achieve team goals by sparing no efforts (Powell, Piccoli, \& Ives, 2004). Working in the dynamic and competitive work sphere, cohesiveness among virtual team members could be considered one of the most important drives for success (Garrison, Wakefield, Xu, \& Kim, 2010; Schwanda, Barron, Lien, Schroeder, Vernon, \& Hancock, 2011; Schroeder, 2011).

The concept of cohesiveness could be divided into two dimensions: task cohesiveness and interpersonal cohesiveness (Gross \& Martin, 1952); the former concerns about team members' commitment to missions and tasks while the later focus on eliminating communication obstacles and improving team coordination. Previous studies have proved a positive relationship between team cohesiveness and team effectiveness (Zaccaro \& Lowe, 1988; Zaccaro \& McCoy, 1988). Team cohesiveness is also closely related to team members' satisfaction, the attendance and the turnover rate of team members; it could be concluded that teams with high cohesiveness could not only achieve goals with lower communication and cooperation costs, but also gain competitive advantage by high efficiency and flexibility (Muellner, 2008).

Based on the above discussion, Hypothesis 3 could then be proposed as follows:

\section{H3: Cohesiveness of the virtual team will positively affect the cooperation among virtual team members.}

\subsubsection{Communication}

Communication is the process of transferring concepts, attitudes, or messages from the sender to the receiver through a specific channel (Dimbleby \& Burtom, 2007; Hertel, Konradt, \& Orlikowski, 2004; Newhagen \& Rafaeli, 1996; Rogers \& Agarwala-Rogers, 1976; Ross, 1983; Shannon, 1949). The main purposes of communication are transmitting information, expressing emotions, and improving understandings among different participants. In the context of virtual team, frequent communication would be helpful for increasing understanding about other members and for cultivating the feeling of belongingness (Jarvenpaa \& Leidner, 1999). Seven crucial components have to work seamlessly to ensure a smooth process of communication, including: the sender, encoding, the message, the channel, decoding, the receiver, and feedback (Robbins, 1991).

With the advancement of information technology, choosing a right communication tool becomes a tricky issue. Unlike traditional teams, members of virtual teams require different communication tools to build trust and improve cohesiveness (Furumo \& Pearson, 2006; Guo, D’Ambra, Turner, \& Zhang, 2009). Hertel, Konradt, \& Orlikowski (2004) proposed that utilizing communication tools could help virtual teams strengthen cohesiveness among members. It is also believed that, in the context of virtual team, communication tools embedding richer information could help improve team performance (Montoya, Massey, Hung, \& Crisp, 2009; Schmitz \& Fulk, 1991). However, the current study argues that too much communication might affect the effectiveness as well as the efficiency of team performance; in other word, a moderating effect is expected on the relationship between team cooperation and team performance. The fourth hypothesis is then formulated as follows:

H4: Communication has a moderating effect on the relationship between team cooperation and team performance.

The research framework is depicted in Figure 1. 


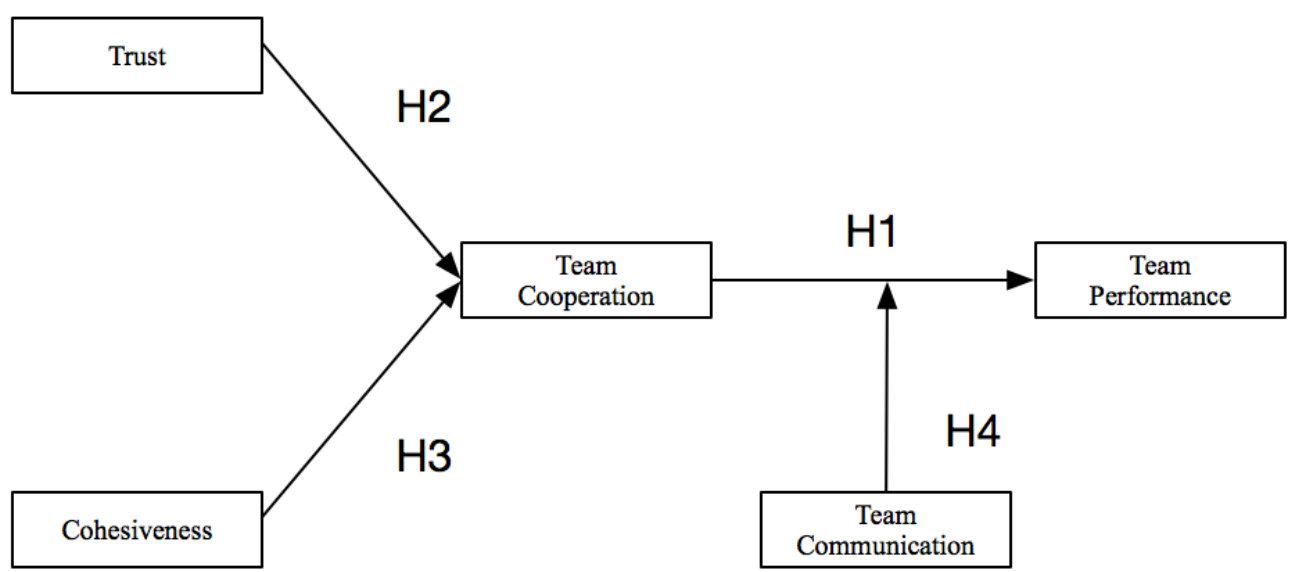

\section{Research Method}

Figure 1. Research Framework

\subsection{Research Instrument}

On-line survey was utilized for collecting data in the current study. Most of the items were adopted from previous studies with necessary modifications; after a series of validating steps, a six-point Likert scale with 22 items was formulated. Descriptions about the items are provided in the following paragraph.

First of all, four items modified from Garrison, Wakefield, Xu, \& Kim (2010) were used to measure trust among virtual team members. Secondly, for measuring cohesiveness, four items proposed by Garrison, Wakefield, Xu, \& Kim (2010) were adopted for the current study. Respondents were asked to express their feeling about the belongingness, happiness, and willingness of participating in a specific virtual team. Cooperation was measured by 5 items adopted from Lin, Baruch, \& Shih, (2012); respondents' willingness to share duties, take responsibilities, and jointly search for solutions were used to understand cooperation among virtual team members. Four items adopted from Chiu, Hsu, \& Wang (2006) were used to measure the condition of communication; relationships, interactions, and the closeness of virtual team members, and the frequency of communicating were considered important indicators. Finally, team performance was measured by 5 items designed by Taiga \& Florian (2012); the degree of achieving goals, the completion of tasks, and the fulfillment of mission requirements were critical checkpoints.

In addition to the above mentioned 22 items used for measuring five variables, 8 demographic items were included to get a general idea of the respondents, including: gender, marriage status, age, occupation, educational background, monthly income, daily average time spent on line, and his/her seniority of playing MMORPGs.

All items are listed in Table 1. 
Table 1. Items Used for Collecting Data

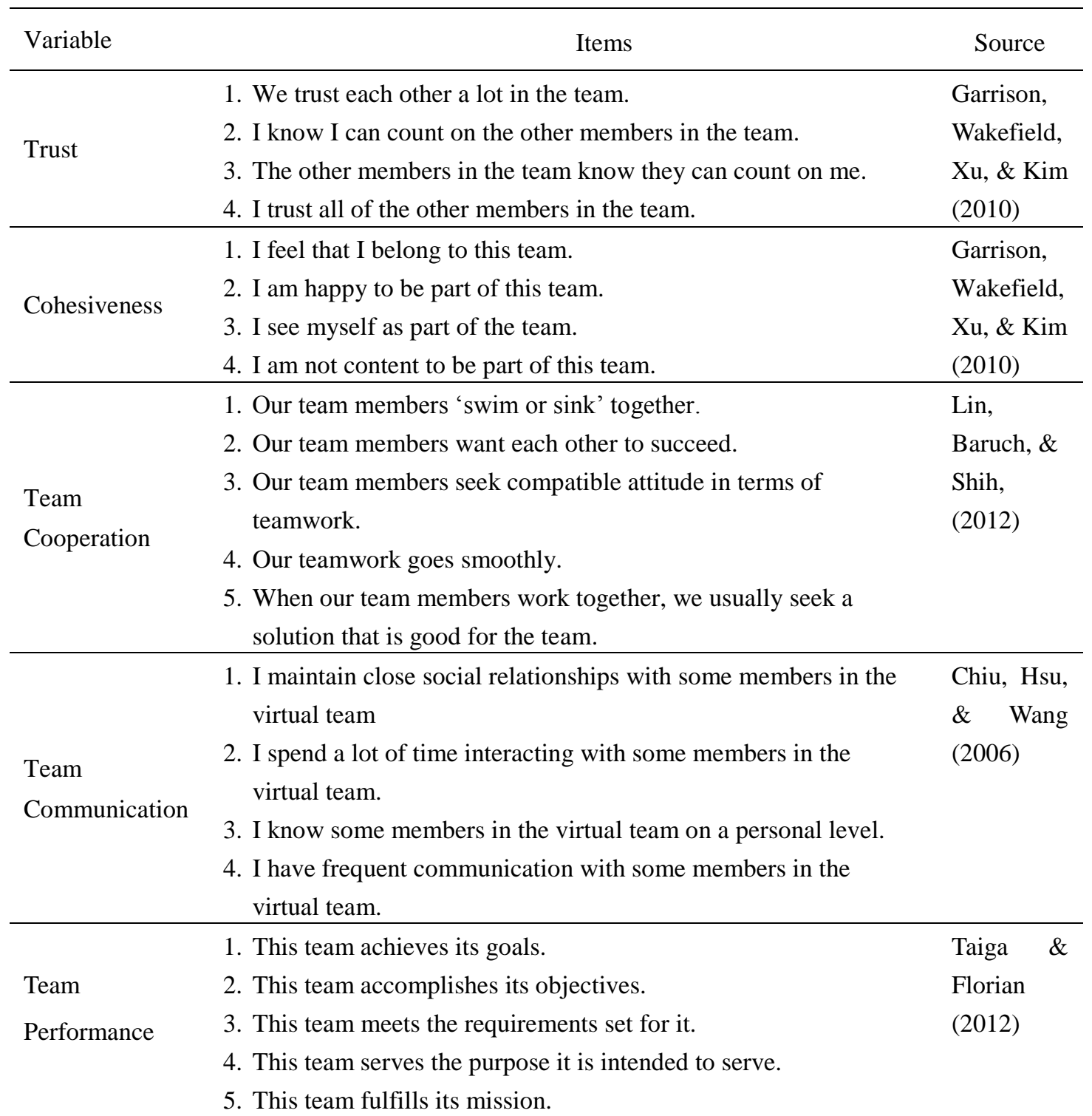

\subsection{Data Collection Process}

It's a well accepted fact that different kinds of virtual teams have been used by practitioners to achieve operational goals; however, it's not possible to get permission from companies to collect enough data from different virtual team members in a specific company. After a series of consultation with scholars and experts, players of MMORPGs players were chosen as suitable targets for collecting data. As mentioned before, players of MMORPGs and members of virtual teams are quite similar during the process of completing tasks and assignments; trust, cohesiveness, cooperation, and communication are key elements for achieving operational excellence.

A paper-based pretest of 113 participants (response rate $=91.87 \%$ ) with experiences of playing MMORPGs was firstly conducted; necessary modification of the items is made after analyzing results of the pretest. A formal on-line survey is then deployed by announcing the research project in several MMORPGs communities for attracting potential respondents to participate. The overwhelming responses from MMORPGs communities were quite amazing; without any rewards for participating the current study, 1765 complete questionnaire are received (29 of them are non-usable, 1736 of them would be used for verifying hypotheses) in one week. The results of analyzing the collected data are presented in the next section. 


\section{Results}

\subsection{Descriptive Analysis}

Before conducting descriptive analysis, the results of reliability test should be provided. Based on the values of Chronbach's $\alpha$ for different variables (ranged from 0.889 to 0.962 ), a fairly high reliability of the research instrument was secured. As the items were adopted from previous study, face validity of the research instrument was also confirmed.

As for the results of descriptive analysis, firstly, more than 90 percent of the collected questionnaires are completed by male $(\mathrm{N}=1577)$; only 159 female participants are female. Most of the respondents are not married $(\mathrm{N}=1625)$; only 111 married respondents participate the current study. 1540 respondents are aged under 30. It's a common belief that most of the MMORPGs players are college students; from the collected questionnaires, 1091 respondents are currently students of different level of educational institute; the rest are almost equally distributed in different industries. Moreover, about 60 percent of the respondents have bachelor degrees of various majors, and the monthly income for about 80 percent of the respondents is less than 30000 NTD. Around $85 \%$ of the respondents spend more than 2 hours surfing on the Internet every day; finally, more than $75 \%$ of the respondents have experience of playing MMORPGs for more than 5 years.

\subsection{Results of Hypotheses Testing}

Regression analysis was utilized to verify the plausibility of hypotheses proposed from the current study. In the following sections, results of regression analysis on different hypotheses are provided.

The first hypothesis was formulated to test the causal relationship between team communication and the performance of the virtual team. As demonstrated in Table 2, a value of 0.259 is derived for $\mathrm{R}^{2}$ with $\mathrm{F}$ value equals to 541.147 and the value of standardized $\beta$ equals to 0.51 ( $\mathrm{p}<0.001)$; the results indicate that $\mathrm{H} 1$ cannot be rejected.

Table 2. Summary of Regression Analysis - Team Cooperation on Team Performance

\begin{tabular}{lccccc}
\hline $\begin{array}{l}\text { Regression } \\
\text { Model }\end{array}$ & Adjusted $\mathrm{R}^{2}$ & F Value & $\begin{array}{c}\text { Standardized } \\
\beta\end{array}$ & t Value & Sig. \\
\hline $\begin{array}{l}\text { Team } \\
\begin{array}{l}\text { Cooperation } \\
\text { on Team }\end{array}\end{array}$ & .259 & 541.147 & .510 & 23.263 & .000 \\
Performance & & & & & \\
\hline
\end{tabular}

The second hypothesis concerned about the role played by trust among virtual team members on their cooperation with others to achieve operational goals. The results derived from regression analysis are listed in Table 3 . With the value of $R^{2}$ equals to 0.546 and the value of $F$ equals to $1853.276(p<0.001)$, it is concluded that $\mathrm{H} 2$ cannot be rejected (the value of standardized $\beta$ is 0.739 ).

Table 3. Summary of Regression Analysis - Trust on Team Cooperation

\begin{tabular}{lccccc}
\hline $\begin{array}{l}\text { Regression } \\
\text { Model }\end{array}$ & Adjusted $\mathrm{R}^{2}$ & F Value & $\begin{array}{c}\text { Standardized } \\
\beta\end{array}$ & t Value & Sig. \\
\hline $\begin{array}{l}\text { Trust on Team } \\
\text { Cooperation }\end{array}$ & .546 & 1853.276 & .739 & 43.050 & .000 \\
\hline
\end{tabular}

The third hypothesis aimed at understanding the effect of cohesiveness of the virtual team on team members' cooperative behaviors to accomplish tasks and assignments. As demonstrated in Table 4 , an $\mathrm{R}^{2}$ value of 0.576 is obtained from regression analysis with the $\mathrm{F}$ value equals to 2093.865 and the value of standardized $\beta$ equals to 0.759 . Therefore, it could be concluded that $\mathrm{H} 3$ cannot be rejected.

Table 4. Summary of Regression Analysis - Cohesiveness on Team Cooperation

\begin{tabular}{lccccc}
\hline $\begin{array}{l}\text { Regression } \\
\text { Model }\end{array}$ & Adjusted $\mathrm{R}^{2}$ & F Value & $\begin{array}{c}\text { Standardized } \\
\beta\end{array}$ & t Value & Sig. \\
\hline $\begin{array}{l}\text { Cohesiveness } \\
\text { on Team }\end{array}$ & .576 & 2093.865 & .759 & 45.759 & .000 \\
\begin{tabular}{l} 
Cooperation \\
\hline
\end{tabular} & & & & & \\
\hline
\end{tabular}

Finally, the last hypothesis focused on the moderating effect of team communication on the performance of the virtual team. After including communication to the regression model, as depicted in Table 5, the positive effect of team cooperation on team performance (the value of standardized $\beta$ ) is decreased from 0.510 to 0.48 . The results indicate that too much communication among virtual team members might jeopardize the cooperative relationship of 
the virtual team and threaten the performance achieved by the virtual team.

Table 5. Summary of Regression Analysis

\begin{tabular}{lccccc}
\hline $\begin{array}{l}\text { Regression } \\
\text { Model }\end{array}$ & Adjusted $\mathrm{R}^{2}$ & F Value & $\begin{array}{c}\text { Standardized } \\
\beta\end{array}$ & t Value & Sig. \\
\hline $\begin{array}{l}\text { Interaction of } \\
\begin{array}{l}\text { Communication } \\
\text { and Team }\end{array}\end{array}$ & & & & & \\
$\begin{array}{l}\text { Cooperation on } \\
\text { Team }\end{array}$ & .200 & 386.494 & .448 & 19.659 & .000 \\
Performance & & & & & \\
\hline
\end{tabular}

\section{Conclusion, Limitation, \& Suggestions}

Using data collected from players of MMORPGs, the current study proposed four hypotheses to verify relationships between different variables and virtual team performance. Precisely speaking, the results indicate that, based on the data collected from an online survey, team cooperation, trust, and cohesiveness among virtual team members do have positive relationships with virtual team performance; the effects of those variables on team performance are quite similar for both traditional face-to-face teams and virtual teams. Surprisingly, communication among virtual team members, as indicated by the existence of the moderating effect, might decrease the influence of virtual team cooperation on virtual team performance. The author conducted interviews with several participants of the current study after finishing the data analysis procedure to figure out the rationale of the phenomenon; based on the opinions and observation of the MMORPGs players, it could be concluded that, due to the fact that players of MMORPGs have different backgrounds, communication obstacles and inefficient communication might decrease the willingness for further communication and then compromise the collective performance of the virtual team. Moreover, the characteristic of instantaneity for MMORPGs might even trigger negative emotional responses from members of the same virtual team and decrease the willingness for further cooperation. The findings of this study are consistent with previous studies which found similar relationships between cooperation, trust, cohesiveness, and performance (Ansari \& Riasi, 2016). These findings can be applied to various other domains including financial services (Riasi, 2015), marketing (Ansari \& Riasi, 2016), educational management (Riasi \& Asadzadeh, 2015), etc.

Although lots of data were collected for analysis in the current study, several limitations deserve further explanation. First of all, the current study takes a cross-sectional viewpoint; without a longitudinal understanding, critical information such as the formation of the virtual team might be neglected. Secondly, the current study collected data from players of MMORPGs; although MMORPGs and tasks or assignments of virtual teams share some common features, unique characteristics of virtual teams might be left unnoticed (e.g., the purpose of forming a virtual team, the willingness of participating a virtual team, and etc.). Thirdly, for virtual teams operating in the real world, team members might come from different cultural backgrounds; the diversity of the respondents in the current study might not be able to reflect the real situation.

Undoubtedly, adopting virtual team for accomplishing different tasks is a fact and a growing trend for practitioners to secure competitive advantages. In order to make the best use of virtual teams, it is critical to thoroughly understand factors that might affect the performance of virtual teams. Actually, a plethora of studies on traditional teams have laid a solid foundation for further research; studies on different types of virtual teams, a longitudinal perspective of virtual team study, and the comparison of the effects of critical factors on traditional teams and virtual teams are considered plausible directions for further study.

\section{Acknowledgement}

The author would like to express his gratitude to Shih Yu, Ni and Chih-Chun, Li during the process of collecting literature, organizing on-line survey, and analyzing data. The current study would not be able to accomplish its original goal without their devotion.

\section{References}

Ansari, A., \& Riasi, A. (2016). An Investigation of Factors Affecting Brand Advertising Success and Effectiveness. International Business Research, 9(4), 20-30. http://dx.doi.org/10.5539/ibr.v9n4p20

Barrick, M. R., Stewart, G. L., Neubert, M. J., \& Mount, M. K. (1998). Relating Member Ability and Personality to Work-team Processes and Team Effectiveness. Journal of Applied Psychology, 83(3), 377-391. http://dx.doi.org/10.1037/0021-9010.83.3.377 
Bergiel, B. J., Bergiel, E. B., \& Balsmeier, P. W. (2008). Nature of Virtual Teams: A Summary of Their Advantages and Disadvantages. Management Research News, 31(2), 99-110. http://dx.doi.org/10.1108/01409170810846821

Bosch-Sijtsema, P. (2007). The Impact of Individual Expectations and Expectation Conflicts on Virtual Teams. Group Organization Management, 32(3), 358-388. http://dx.doi.org/10.1177/1059601106286881

Brahm, T. \& Kunze, F. (2012). Increasing the Performance of Virtual Teams: The Context Role of Trust Climate. In Proceedings of the $7^{\text {th }}$ Annual INGRoup Conference 2012.

Canney-Davison, S., \& Ward, K. (1999). Leading International Teams, London: McGraw-Hill.

Chatman, J. A., \& Flynn, F. J. (2001). The Influence of Demographic Heterogeneity on the Emergence and Consequences of Cooperative Norms in Work Teams. Academy of Management Journal, 44(5), 956-974. http://dx.doi.org/10.2307/3069440

Chiu, C.M., Hsu, M.H., \& Wang, E. T. G. (2006). Understanding Knowledge Sharing in Virtual Communities: An Integration of Social Capital and Social Cognitive Theories, Decision Support Systems, 42(3), 1872-1888. http://dx.doi.org/10.1016/j.dss.2006.04.001

Cohen, S. G., Ledford Jr., G. E., \& Spreitzer, G. M. (1996). A Predictive Model of Self-Managing Work Team Effectiveness. Human Relations, 49(5), 643-676. http://dx.doi.org/10.1177/001872679604900506

Connelly, C. E., \& Kelloway, E. K. (2003). Predictors of Employees Perceptions of Knowledge Sharing Cultures. Leadership and Organization Development Journal, 24(5), 294-301. http://dx.doi.org/10.1108/01437730310485815

Daley. D. M., \& Vasu, M. L. (1998). Fostering Organizational Trust in North Carolina: The Pivotal Role of Administrators and Political Leaders. Administration and Society, 30(1), 62-84. http://dx.doi.org/10.1177/009539979803000105

Deutsch, M. (1977). The Resolution of Conflict: Constructive and Destructive Process. New Haven, CT: Yale University Press. http://dx.doi.org/10.1177/000276427301700206

Dimbleby, R., \& Burton, G. (2007). More Than Words: An Introduction to Communication. London, United Kingdom: Routledge

Ellis, A. P., Hollenbeck, J. R., Illgen, D. R., Porter, C. O., West, B. J., \& Moon, H. (2003). Team Learning: Collectively Connecting the Dots. Journal of Applied Psychology, 88(5), 821-835. http://dx.doi.org/10.1037/0021-9010.88.5.821

Festinger, L., Schachter, S., \& Back, K. W. (1983). Social Pressures in Informal Groups: A Study of Human Factors in Housing. Redwood City, CA: Stanford University Press. http://dx.doi.org/10.2307/3707362

Furumo, K., \& Pearson, J. M. (2006). An Empirical Investigation of how Trust, Cohesion, and Performance Vary in Virtual and Face-to-Face Teams. In Proceedings of the $39^{\text {th }}$ Hawaii International Conference on System Sciences, 1-10. http://dx.doi.org/10.1109/HICSS.2006.51

García, C.Q., \& Velasco, C. A. B. (2002). Co-opetition and Performance: Evidence from European Biotechnology Industry. In Proceedings of the $2^{\text {nd }}$ Annual Conference of EURAM on Innovative Research in Management.

Garrison, G., Wakefield, R. L., Xu, X., \& Kim, S. H. (2010). Globally Distributed Teams: The Effect of Diversity on Trust, Cohesion and Individual Performance. ACM SIGMIS Database, 41(3), 27-48. http://dx.doi.org/10.1145/1851175.1851178

Gersick, C. J. G., \& Hackman, J. R. (1990). Habitual Routines in Task-Performing Groups. Organizational Behavior and Human Decision Processes, 47(1), 65-97. http://dx.doi.org/10.1016/0749-5978(90)90047-D

Gross, N., \& Martin, W. E. (1952). On Group Cohesiveness. American Journal of Sociology, 57(6), 546-564. http://dx.doi.org/10.1086/221041

Guo, Z., D’Ambra, J., Turner, T., \& Zhang, H. (2009). Improving the Effectiveness of Virtual Teams: A Comparison of Video-Conferencing and Face-to-Face Communication in China. IEEE Transactions on Professional Communication, 52(1), 1-16. http://dx.doi.org/10.1109/TPC.2008.2012284

Hertel, G., Konradt, U., Orlikowski, B. (2004). Managing Distance by Interdependence: Goal Setting, Task Interdependence, and Team-Based Rewards in Virtual Teams. European Journal of Work and Organizational Psychology, 13(1), 1-28. http://dx.doi.org/10.1080/13594320344000228 
Hoegl, M., \& Gemuenden, H. G. (2001). Teamwork Quality and the Success of Innovative Projects: A Theoretical Concept and Empirical Evidence. Organization Science, 12(4), 435-449. http://dx.doi.org/10.1287/orsc.12.4.435.10635

Igbaria, M., \& Guimaraes, T. (1999). Exploring Differences in Employee Turnover Intentions and Its Determinants Among Telecommuters and Non-Telecommuters. Journal of Management Information Systems, 16(2), 147-164. http://dx.doi.org/10.1080/07421222.1999.11518237

Jarvenpaa, S. L., \& Leidner, D. E. (1999). Communication and Trust in Global Virtual Teams. Organization Science, 10(6), 791-815. http://dx.doi.org/10.1287/orsc.10.6.791

Johnson, D. W. (1973). Communication in Conflict Situations: A Critical Review of the Research. International Journal of Group Tensions, 3(1), 46-67.

Karau, S. J., \& Williams, K. D. (1993). Social Loafing: A Meta-Analytic Review and Theoretical Integration. Journal of Personality and Social Psychology, 65(4), 681-706. http://dx.doi.org/10.1037/0022-3514.65.4.681

Khazanchi, D., \& Zigurs, I. (2005). Patterns of Effective Management of Virtual Projects: An Exploratory Study. Newton Square, PA: Project Management Institute. http://dx.doi.org/10.4018/978-1-60566-652-5.ch098

Kraut, R. E., \& Streeter, L. A. (1995). Coordination in Software Development. Communications of the ACM, 38(3), 69-81. http://dx.doi.org/10.1145/203330.203345

Lane, C. (1998). Introduction: Theories and Issues in the Study of Trust. In C. Lane \& R. Bachmann (Eds.), Trust Within and Between Organizations: Conceptual Issues and Empirical Applications (pp. 1-30). New York: Oxford University Press.

Leenders, R. Th. A. J., van Engelen, J. M. L., \& Kratzer, J. (2003). Virtuality, Communication, and New Product Team Creativity: A Social Network Perspective. Journal of Engineering and Technology Management, 20(1-2), 69-92. http://dx.doi.org/10.1016/S0923-4748(03)00005-5

Lin, C. P., Baruch, Y., \& Shih, W. C. (2012). Corporate Social Responsibility and Team Performance: The Mediating Role of Team Efficacy and Team Self-Esteem. Journal of Business Ethics, 108(2), 167-180. http://dx.doi.org/10.1007/s10551-011-1068-6

Lipnack, J., \& Stamps, J. (1997). Virtual Teams: Reaching Across Space, Time, and Organizations with Technology. New York, NY: John Wiley and Sons.

Lipnack, J., \& Stamps, J. (1999). Virtual Teams: The New Way to Work. IEEE Engineering Management Review, 27(4), 90-95. http://dx.doi.org/10.1108/eb054625

Majchrzak, A., Rice, R. E., King, N., Malhotra, A., \& Ba, S. (2000a). Computer Mediated Inter-Organizational Knowledge-Sharing: Insights from a Virtual Team Innovating Using a Collaborative Tool. Information Resources Management Journal, 13(1), 44-53. http://dx.doi.org/10.4018/irmj.2000010104

Majchrzak, A., Rice, R. E., King, N., Malhotra, A., \& Ba, S. (2000b). Technology Adaptation: The Case of a Computer-Supported Inter-Organizational Virtual Team. MIS Quarterly, 24(4), 569-600. http://dx.doi.org/10.2307/3250948

Malone, T. W., \& Crowston, K. (1994). The Interdisciplinary Study of Coordination. ACM Computing Surveys, 26(1), 87-119. http://dx.doi.org/10.1145/174666.174668

Maznevski, M. L., \& Chudoba, K. M. (2000). Bridging Space Over Time: Global Virtual Team Dynamics and Effectiveness. Organization Science, 11(5), 473-492. http://dx.doi.org/10.1287/orsc.11.5.473.15200

McLean, J. (2007). Managing Global Virtual Teams. British Journal of Administrative Management, 59(2), 16-17.

Meyerson, D., Kramer, R. M., \& Weick, K. E. (1996). Swift Trust and Temporary Groups. In R. M. Kramer and T. R. Tyler (Eds.), Trust in Organization: Frontiers of Theory and Research (pp.166-195). Thousand Oaks, CA: Sage Publications. http://dx.doi.org/10.4135/9781452243610.n9

Montoya, M. M., Massey, A. P., Hung, Y. T. C., \& Crisp, C. B. (2009). Can You Hear Me Now? Communication in Virtual Product Development Teams. Journal of Product Innovation Management, 26(2), 139-155. http://dx.doi.org/10.1111/j.1540-5885.2009.00342.x

Muellner, H. (2008). The Effect of Online Conducted Team Building Procedures On Initial Cohesion and Performance of Virtual Teams. International Journal of Psychology, 43(3), 27. 
Nahapiet, J., \& Ghoshal, S. (1998). Social Capital, Intellectual Capital, and the Organizational Advantage. The Academy of Management Review, 23(2), 242-266. http://dx.doi.org/10.5465/AMR.1998.533225

Nemiro, J., Beyerlein, M., Bradley, L., \& Beyerlein, S. (2008). The Handbook of High-Performance Virtual Teams: A Toolkit for Collaborating Across Boundaries. Francisco, CA: Jossey-Bass.

Newhagen, J. E., \& Rafaeli, S. (1996). Why Communication Researchers Should Study the Internet: A Dialogue. Journal of Communication, 46(1), 4-13. http://dx.doi.org/10.1111/j.1460-2466.1996.tb01458.x

Oh, H., Labianca, G., \& Chung, M. H. (2006). A Multilevel Model of Group Social Capital. The Academy of Management Review, 31, 569-582. http://doi.org/10.5465/AMR.2006.21318918

O’Leary, M. B., \& Mortensen, M. (2010). Go (Con)figure: Subgroups, Imbalance, and Isolates in Geographically Dispersed Teams. $\quad$ Organization $\quad$ Science, $\quad 21(1), \quad 115-131$. http://doi.org/10.1287/orsc.1090.0434

Patrashkova-Volzdoska, R. R., McComb, S. A., Green, S. G., \& Compton, W. D. (2003). Examining a Curvilinear Relationship between Communication Frequency and Team Performance in Cross-Functional Project Teams. IEEE Transactions on Engineering Management, 50(3), 262-269. http://doi.org/10.1109/TEM.2003.817298

Politis, J. D. (2003). The Connection between Trust and Knowledge Management: What are its Implications for Team Performance. Journal of Knowledge Management, 7(5), 55-66. http://doi.org/10.1108/13673270310505386

Powell, A., Piccoli, G., \& Ives, B. (2004). Virtual Teams: A Review of Current Literature and Directions for Future Research. ACM SIGMIS Database, 35(1), 6-36. http://dx.doi.org/10.1145/968464.968467

Putnam, R. D., Leonardi, R., \& Nanetti, R. Y. (1994). Making Democracy Work: Civic Traditions in Modern Italy. New Jersey: Princeton University Press.

Riasi, A. (2015). Competitive Advantages of Shadow Banking Industry: An Analysis Using Porter Diamond Model. Business Management and Strategy, 6(2), 15-27. http://dx.doi.org/10.5296/bms.v6i2.8334

Riasi, A., \& Asadzadeh, N. (2016). How Coercive and Legitimate Power Relate to Different Conflict Management Styles: A Case Study of Birjand High School. Journal of Studies in Education, 6(1), 147-159. http://dx.doi.org/10.5296/jse.v6i1.8946

Rico, R., Sánchez-Manzanares, M., Gil, F., \& Gibson, C. (2008). Team Implicit Coordination Processes: A Team Knowledge-Based Approach. The Academy of Management Review, 33(1), 163-184. http://doi.org/10.5465/AMR.2008.27751276

Robbins, S. P. (1991). Management ( $3^{\text {rd }}$ ed.). England Cliff: NJ: Prentice-Hall.

Robert, L. P., Denis, A. R., \& Hung, Y. C. (2009). Individual Swift Trust and Knowledge-Based trust in Face-To-Face and Virtual Team Members. Journal of Management Information Systems, 26(2), 241-279. http://doi.org/10.2753/MIS0742-1222260210

Robey, D., Khoo, H. M., \& Powers, C. (2000). Situated Learning in Cross-functional Virtual Teams. IEEE Transactions on Professional Communication, 43(1), 51-66. http://doi.org/10.1109/47.826416

Rogers, E. M., \& Agarwala-Rogers, R. (1976). Communication in Organization. New York: Free Press.

Ross, R. S. (1983). Speech Communication $\left(6^{\text {th }}\right.$ ed). New Jersey: Prentice-Hall.

Schmitz, J., \& Fulk, J. (1991). Organizational Colleagues, Media Richness, and Electronic Mail: A Test of the Social Influence Model of Technology Use. Communication Research, 18(4), 487-523. http://doi.org/10.1177/009365091018004003

Schwanda, V. L., Barron, K., Lien, J., Schroeder. G., Vernon, A., \& Hancock, J. T. (2011). Temporal Patterns of Cohesiveness in Virtual Groups. In CSCW'11 Proceedings of the ACM 2011 Conference on Computer Supported Cooperative Work, 709-712. http://doi.org/10.1145/1958824.1958951

Schroeder, S. A. (2011). Adopting Game Technology for Architectural Visualization (master's thesis). Purdue University, Indiana, USA. Retrieved from http://docs.lib.purdue.edu/cgttheses/6/

Shannon, C. E., \& Weaver, W. (1949). The Mathematical Theory of Communication. Champaign, IL: University of Illinois Press.

Shea, G. P., \& Guzzo, R. A. (1987). Groups as Human Resources. In Rowland, K. M., \& Ferris, G. P. (Eds.), 
Research in Personnel and Human Resources Management (pp 323-356). Greenwich, CT: JAI Press.

Sheng, H., Siau, K., \& Nah, F. F. H. (2010). Understanding the Values of Mobile Technology in Education: A Value-Focused Thinking Approach. Data Base for Advances in Information Systems, 41(2), 24-44. http://dx.doi.org/10.1145/1795377.1795380

Staples, D. S., \& Zhao, L. (2006). The Effects of Cultural Diversity in Virtual Teams Versus Face-To-Face Teams. Group Decision and Negotiation, 15(4), 389-406. http://doi.org/10.1007/s10726-006-9042-x

Tan, B. C. Y., Wei, K. K., Huang, W. W., \& Ng, G. N. (2000). A Dialogue Technique to Enhance Electronic Communication in Virtual Teams. IEEE Transactions on Professional Communication, 43(2), 153-165. http://doi.org/10.1109/47.843643

Tsai, W., \& Ghoshal, S. (1998). Social Capital and Value Creation: The Role of Intrafirm Networks. The Academy of Management Journal, 41(4), 464-476. http://doi.org/10.2307/257085

Van de Ven, A. H., Delbecq, A. L., \& Koening Jr., R. (1976). Determinants of Coordination Modes within Organizations. American Sociological Review, 41(2), 322-338. http://doi.org/10.2307/2094477

Wallace, L., Keil, M., \& Rai, Arun (2004). How Software Project Risk Affects Project Performance: An Investigation of the Dimensions of Risk and an Exploratory Model. Decision Science, 35(2), 289-321. http://doi.org/10.1111/j.00117315.2004.02059.x

Zaccaro, S. J., \& Lowe, C. A. (1988). Cohesiveness and Performance on an Additive Task: Evidence for $\begin{array}{lllll}\text { Multidimensionality. Journal of Social } & \text { Psychology, } & \text { 128(4), }\end{array}$ http://doi.org/10.1080/00224545.1988.9713774

Zaccaro, S. J., \& McCoy, M. C. (1988). The Effects of Task and Interpersonal Cohesiveness on Performance of a Disjunctive Group Task. Journal of Applied Social Psychology, 18(10), 837-851. http://doi.org/10.1111/j.1559-1816.1988.tb01178.x 